\title{
Streptococcal infection-related autoimmunity and autism: crosstalk in protein functional networks
}

\author{
Megan Huxley ${ }^{1}$, Joshua Stead ${ }^{1}$ and Olga Vasieva ${ }^{1,2 *}$ \\ ${ }^{1}$ Institute of Integrative Biology, University of Liverpool, Crown St., Liverpool L69 7ZB, UK \\ ${ }^{2}$ Ingenet Ltd, 3d floor 207 Regent Street, London, England W1B 3HH, UK
}

\begin{abstract}
Autism Spectrum Disorders (ASD) is a group of neurodevelopment dysfunctions causing behavioral abnormalities in social, verbal and non-verbal communication. The precise aetiology of ASD is unknown but it is likely to be the outcome of a combination of genetic, neurological, environmental and immunological factors. Streptococcal infection can induce tick disorders and obsessive compulsive disorder (OCD) which are described as 'co morbid' ASD, however the link between the outcomes or susceptibility to the infection and ASD is not clear. In this study we aimed to establish, via data mining and convergent genomics analysis, functional interactions between the targets of auto-antigens produced during Streptococcal infection, and genes linked to ASD via genome wide association and experimental studies. The results point towards a relation of immune and, particularly, autoimmune responses caused by Streptococcal infection to functions associated with ASD disorder. Our study also highlights a need in further experimental research into an autoimmune aetiology of autism and movement disorders characteristic for Pediatric Autoimmune Neuropsychiatric Disorders Associated with Streptococcal Infections (PANDAS).
\end{abstract}

\section{Introduction}

Autism spectrum disorders (ASD) is an umbrella term for a variety of neurodevelopmental disorders that are characterised by abnormalities in verbal, nonverbal and social communication [1]. ASD affects around 700,000 people in the UK [2]. Disorders governed by this term include tic disorders, ADHD and autism. ASD is a relatively new term in medicine and there is little research into its etiopathogenesis. The multifactorial aetiology and the variance within ASD make it difficult to identify the cause. Long-term twin studies have indicated that there may be environmental factors that have a large part to play in the onset of ASD [3]. Evidence is mounting that ASD is caused by gene-environment interactions with an everyday substance such as a protein found in milk, Butyrophilin, for instance, causing potential autoimmune impact mimicking the nervous system (NS) antigen MOG (myelin oligodendrocyte glycoprotein) [4]. Studies have also tried to link prenatal factors, such as maternal medication, maternal age and birth order to the onset of ASD; despite modest indications, there is insufficient evidence to determine a definitive risk factor $[5,6]$.

There is also known to be a genetic risk factor to ASD, where genetic perturbations may increase susceptibility to developing autism. Multiple genes have been identified as potential candidates for ASD, however none of these candidates account for more than 1-2\% of ASD cases [7]. In addition, there is variety in the roles of the candidate genes, with no established archetype; this makes it very difficult to find a set cause and therapy for ASD. One candidate risk factor is CNTNAP2, from the neurexins superfamily, which has variants that can increase the likeliness of ASD through the alteration of transcription factor binding site [8]. Another candidate that has been found within some ASD patients is Shank3, which codes for a scaffolding protein located in synapses [9].

Studies have shown that Shank3 mutations lead to altered behaviors that are similar to ASD patients, in mice [10]. Campbell, et al. [11] found genetic variants of MET to be associated with ASD; $M E T$ is a receptor tyrosine kinase and has roles in brain development and immune system regulation. However, studies on candidate genes so far have not been definitive due to small sample sizes, variation in phenotypes and poor controls. It may be also that non- syndromic ASD depends on certain combinations of mutations.

Transcriptomic analysis shows the post-mortem brains of ASD patients have downregulated neural genes and upregulated genes involved with an immune response [12], and perturbations in immune system of ASD patients have been reported [13-15]. Mounting evidence has found elevated levels of reactive autoantibodies (anti-GFAP (glial fibrillary glycoprotein), anti-MBP (myelin basic protein), anti-MOG and anti-NAFP (neuron axon filament protein)) in ASD patients compared to unaffected patients [16-19]. Although, there is still some disagreement with some studies suggesting that there is no evidence of autoimmune response in ASD [20].

Streptococcal (Group A $\beta$-haemolytic streptococcal [GABHS]) infection can induce autoimmune disease in humans. Pediatrics Autoimmune Neuropsychiatric Disorders Associated with Streptococcal Infections (PANDAS) are a group of disorders caused by streptococcal infections in children and play a role in the onset of tick disorders and OCD [21]. PANDAS are associated with a group of antibodies, which are elevated during disease symptoms and may signal neuronal cells in the brain. The hypothesis is that autoantibodies produced in response to a streptococcal antigen allow cytokines

Correspondence to: Olga Vasieva- $\mathrm{PhD}$, Senior Systems Biology Analyst, Honorary Lecturer- University of Liverpool, Director- Ingenet Ltd, UK

Key words: autism, autoimmunity, functional networks, PANDAS, streptococcal infection.

Received: June 29, 2017; Accepted: July 19, 2017; Published: July 21, 2017 
activated in the periphery to cross the Blood Brain Barrier (BBB), and along with intrathecal antibodies (antibodies in the central nervous system) produced by peripheral B-cells, react with neural structures [22]. Two common antibodies, Antideoxyribonuclease titer-B and Antistreptolysin $\mathrm{O}$ titer-ASO act as described above by crossing the BBB where they cross- react with the vulnerable basal ganglia [23]. When damaged, the basal ganglia region of the brain is associated with disorders such as obsessive compulsive disorder, chorea, and the typical Tic's associated with Tourette's syndrome (TS) [24]. The similarities between PANDAS and some of the disorders that are within the ASD bracket, may suggest a similar etiology $[25,26]$. In literature TS and Obsessive Compulsive Disorder (OCD) have been linked to ASD as 'co morbid' conditions [25]. There is evidence linking childhood streptococcal infections to TS and OCD, however there is very little evidence confirming the exact link if any between childhood infections, and the development of ASD. The current idea, as depicted in Figure 1, is that combinations of autoantibody and cytokine actions cross talk with the NS, which leads to changes in the areas of the brain controlling behaviors [27]. It seems practical to believe that there is genetic susceptibility in individuals and ASD is triggered in them by an environmental/immunity factor such as infection.

Although the current rationale is in support of an autoimmune role in ASD, there is little work done to understand the mechanism behind it. Therefore, the aim of this study was to investigate the roles of streptococcal-autoantibody targets and to try to find a functional link between them and a network of genes suggestively involved in ASD.

\section{Methods}

\section{Data mining}

Online database 'Scopus' was used for literature mining. Search terms autism, autoimmune, childhood and streptococcus were used to produce an initial list of references. This was reduced to 9 by excluding papers that were not relevant, inaccessible or not in English (Figure 2). The

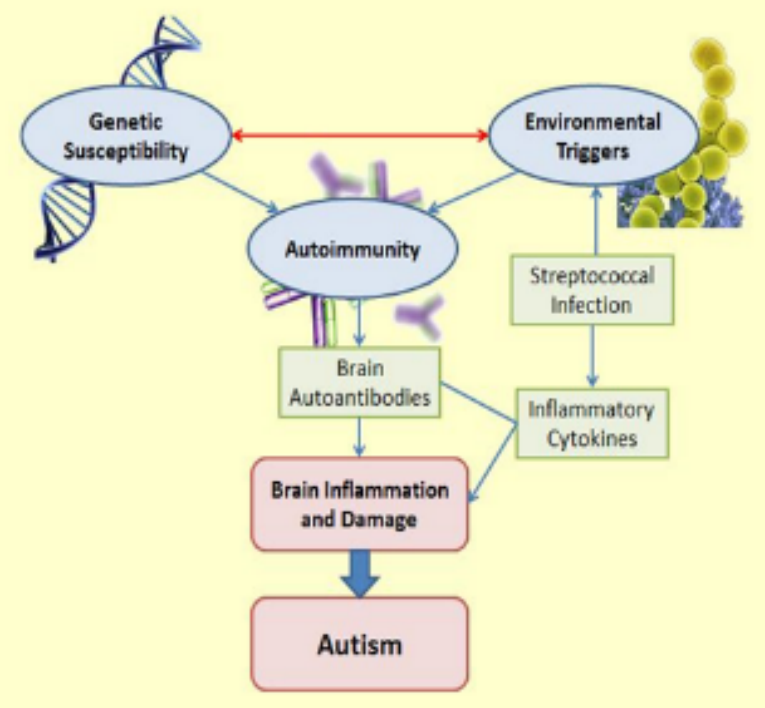

Figure 1. An overview of one hypothesis for the onset of autism. Blue circles indicate key factors thought to be involved in the onset of the disease. Genetic susceptibility and environmental triggers are thought to have an interactive relationship (indicated by red arrow). A genetic susceptibility may mean that individuals are highly reactive to environmental triggers; environmental triggers may lead to a change in gene expression that may render an individual susceptible. Both environmental and genetic factors have a role in the onset of autoimmunity. Streptococcal infections are hypothesised to trigger autoimmune-onset autism

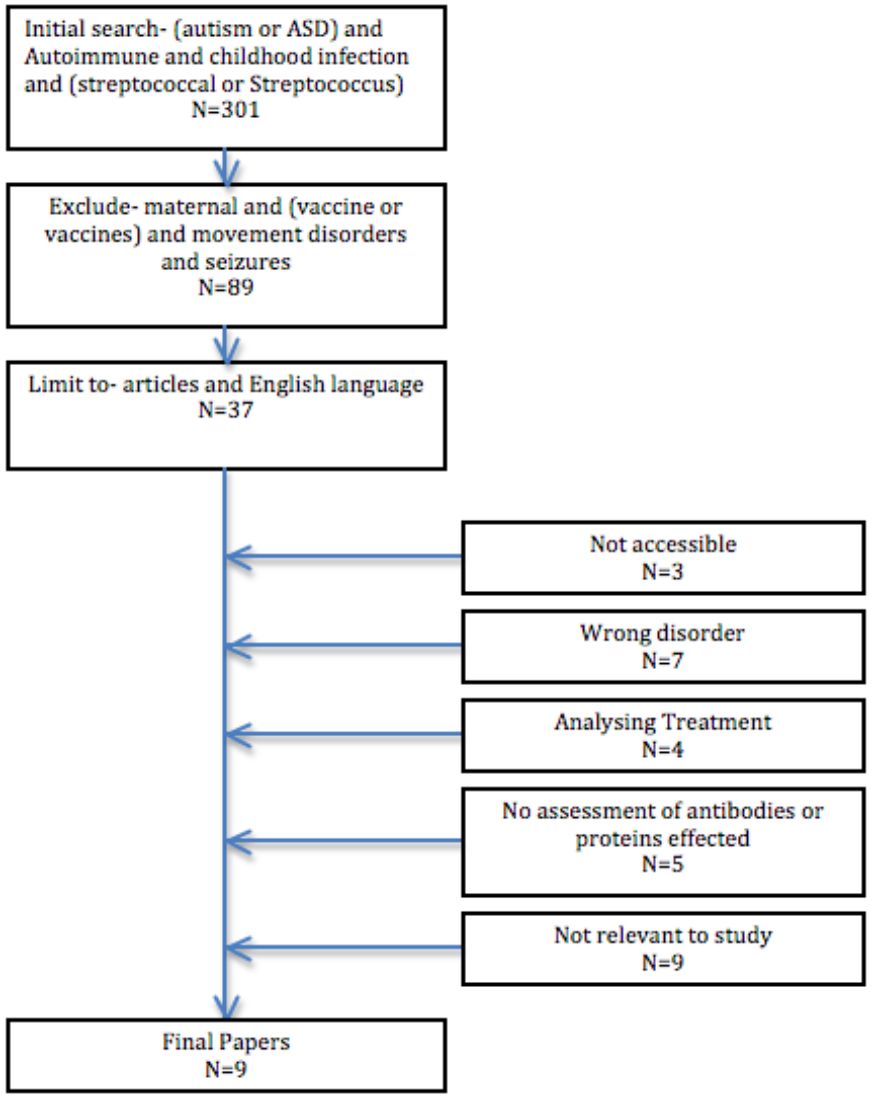

Figure 2. The order of a literature data mining on psychiatric disorders associated with autoimmunity

names (IDs) of autoantibodies that are found to be higher in autistic participants compared to the control groups were used in a further search to determine if they are produced in streptococcal infection.

Once this was confirmed the further search to identify targets of these antibodies was performed and a final list compiled (Supplementary table 1). This data was used in a reconstruction of functional networks linking the antibodies targets to genes relevant to autism (Supplementary table 2). The genes were chosen via GWAS studies by the correlation of relevant SNPs to autistic phenotype (genes) [28-31].

\section{Reconstruction of functional networks}

String software (http://string-db.org/) was used to reconstruct functional networks of the proteins identified in the above data mining process. STRING is a database of known and predicted protein interactions including direct (physical) and indirect (functional) associations derived from four sources; Genomic Context, High Throughput Experiments, Coexpression and Previous Knowledge. White nodes can be added by the software to link proteins that are inputted by the user. Functional network analysis was also performed using Ingenuity Systems (www.ingenuity.com) Ingenuity Pathway Analysis (IPA), where connections of inputted list of genes were established automatically on the basis of the Ingenuity knowledge basedatabase data. And a customised number of the maximum number of the linked nodes the linked nodes was set to 70 .

\section{GO enrichment analysis}

Two methods were used for GO (Gene Ontology) enrichment analysis. The Database for Annotation, Visualization and Integrated 
Discovery (DAVID) version 6.8 (https://david- d.ncifcrf.gov/) was used for GO enrichment analysis. DAVID uses a modified Fisher Exact P value, EASE score to measure gene annotation. String software (http:// string-db.org) 'Analysis' section was used for enrichment analysis (biological functions and cellular component) of a reconstructed STRING network context.

\section{Gene expression analysis}

Genevestigator was used to analyze microarray expression metadata for the selected genes. Both ASD-associated and streptococcal infection-associated genes were analyzed using data from the "mRNA-Seq gene level Homo sapiens" platform, with the default organism being Homo sapiens. The tissue location of expression for the individual genes was found using the 'Anatomy' tool. Expression levels were scored based on their mean score in related units in a scale between the lowest and the highest expression levels of all genes in a particular tissue, mean scores of $\geq 6$, showed high levels of expression

\section{Results}

Our search (Figure 2) lead to 9 research articles, which described a process of autoimmunity, related to Autism, TS or OCD. The result of the search is shown in Table 1. Of the 9 papers, 6 were related to Autism, 2 to TS and one to OCD. The autoimmune antibodies that were mentioned as statistically significant to the above disease were CD19, CD8/17, Anti- Dipeptidylpeptidase IV (Anti-DDP IV), AntiDipeptidylpeptidase I (Anti-DDP I), Anti- Aminopeptidase N, AntiGliadin and Heat Shock Protein-60 peptide, Anti-Ganglioside M1, Anti-HK-I, Anti-VDAC, Anti-Nuclear and Anti-Myelin Basic Protein (Anti-MBP), Anti- Myelin Associated Glycoprotein (Anti-MAG) and TNF $[1,32]$.

\section{Functional interactions of autoantibodies related to Streptococcal Infection}

From these papers only 5 linked streptococcus infections to autoantibodies. The antibodies that were linked to Streptococcus infection were CD19 positive B cells, monoclonal antibody D8/17, Anti-DDP IV, Anti-DDPI, Anti-Aminopeptidase N, Anti-MBP, Heat shock protein- 60 peptide and Anti-MAG. The remaining papers did not provide evidence that streptococcal infection caused the production of the autoantibodies.

Through the further literature mining, the target proteins of the autoantibodies where identified; these proteins and the genes that code for them are shown in Table 2.

The nodes for inputted list of genes, CD19, CHST5, DDP4, ANPEP, MBP, HSPD1 and MAG, but CTSC, where connected with

Table 1. Main results of the literature data mining on psychiatric disorders associated with autoimmunity

\section{Paper Title}

D8/17 and CD19 Expression on Lymphocytes of Patients with Acute Rheumatic Fever and Tourette's Disorder

Progress Toward Analysis of D8/17 Binding to B cells in Children with OCD and/or Chronic Tic Disorder

B Lymphocyte Antigen D8/17 and Repetitive Behaviours in Autism

Heat Shock Protein and Gliadin Peptide Promote Development of Peptidase Antibodies in Children with Autism and Patients with Autoimmune Disease

Increased Serum Levels of Anti-Ganglioside M1 Auto-Antibodies in Autistic Children: Relation to the Disease Severity

Serum Anti-Nuclear Antibodies as a Marker of Autoimmunity in Egyptian Autistic Children

Serum Anti-Myelin - Associated Glycoprotein Antibodies in Egyptian Autistic Children

Association of the Tumour Necrosis Factor -308 A/G Promoter Polymorphism with

Tourette Syndrome

Antibodies Against the Voltage-Dependent Anion Channel (VDAC) and its Protective

Ligand Hexokinase-I in Children with Autism

\begin{tabular}{|c|c|c|}
\hline Author & Auto Antibodies & Disease Studied \\
\hline Weisz, et al. 2004 [33] & CD19-positive B cells & TS \\
\hline $\begin{array}{l}\text { Murphy and Pichichero } \\
2002[26]\end{array}$ & Monoclonal antibody D8/17 & OCD/ Tic Disorders \\
\hline Hollander, et al. 1999 [34] & D8/17-positive cells & Autism \\
\hline Vojdani, et al. 2004 [35] & $\begin{array}{l}\text { Anti-DPP IV } \\
\text { Anti-DPP I } \\
\text { Anti-Aminopeptidase } \\
\text { N, Antigliadin } \\
\text { Anti-HSP-60 }\end{array}$ & Autism \\
\hline $\begin{array}{l}\text { Mostafa and AL-Ayadhi, } \\
2011 \text { [36] }\end{array}$ & Anti-Ganglioside M1 & Autism \\
\hline $\begin{array}{l}\text { Mostafa and Kitchener, } \\
2009 \text { [37] }\end{array}$ & Anti-Nuclear & Autism \\
\hline Mostafa et al, 2008 [19] & $\begin{array}{l}\text { Anti-MBP } \\
\text { Anti-MAG }\end{array}$ & Autism \\
\hline Keszler et al, 2014 [38] & TNF -308 G-allele & $\mathrm{TS}$ \\
\hline $\begin{array}{l}\text { Gonzalez-Gronow et al, } \\
2010 \text { [39] }\end{array}$ & $\begin{array}{l}\text { Anti-HK-I } \\
\text { Anti-VDAC }\end{array}$ & Autism \\
\hline
\end{tabular}

Table 2. Autoantibodies associated with paediatric Streptococcal infection and their targets.

\begin{tabular}{|c|c|c|c|}
\hline Paper Title & Author & Auto Antibodies & Target Protein \\
\hline $\begin{array}{l}\text { D8/17 and CD19 expression on lymphocytes of patients with acute rheumatic fever and } \\
\text { Tourette's disorder }\end{array}$ & Weisz et al, 2004 [33] & CD19-Positive B cells & $\begin{array}{l}\text { Cluster Differentiation } 19 \\
\text { (CD19) }\end{array}$ \\
\hline $\begin{array}{l}\text { Murine Anti-vaccinia Virus D8 Antibodies Target Different Epitopes and Differ in Their } \\
\text { Ability to Block D8 Binding to CSE }\end{array}$ & Matho et al, 2014 [40] & Monoclonal Antibody D8/17 & $\begin{array}{l}\text { Carbohydrate } \\
\text { Sulfotransferase } 15 \\
\text { (CHST15) }\end{array}$ \\
\hline Dipeptidyl peptidase-4 (CD26): knowing the function before inhibiting the enzyme & Matteucci et al, 2009 [41] & Anti-DDP IV & $\begin{array}{l}\text { Adenosine Deaminase } \\
\text { Complexing Protein 2, } \\
\text { (DDP4) }\end{array}$ \\
\hline The Primary Structure and Tissue Distribution of Cathepsin & Kominami et al, 1992 [42] & Anti-DDP I & Cathepsin C (CTSC) \\
\hline Contemporary challenges in autoimmunity & $\begin{array}{l}\text { Shoenfeld and Gershwin, } \\
2009 \text { [43] }\end{array}$ & Anti-Aminopeptidase $\mathrm{N}$ & $\begin{array}{l}\text { Alanyl Aminopeptidase } \\
\text { (ANPEP) }\end{array}$ \\
\hline Antibodies to myelin basic protein in children with autistic behavior. & Singh et al, $1993[16]$ & Anti-MBP & Myelin Basic Protein (MBP) \\
\hline $\begin{array}{l}\text { Heat Shock Protein and Gliadin Peptide Promote Development of Peptidase Antibodies } \\
\text { in Children with Autism and Patients with Autoimmune Disease }\end{array}$ & Vojdani et al, 2004 [35] & Anti-HSP-60 & $\begin{array}{l}\text { Heat Shock } 60 \mathrm{kD} \text { Protein } 1 \\
\text { (HSPD1) }\end{array}$ \\
\hline $\begin{array}{l}\text { The myelin-associated glycoprotein gene: mapping to human chromosome } 19 \text { and mouse } \\
\text { chromosome } 7 \text { and expression in quivering mice. }\end{array}$ & Barton et al, 1987 [44] & Anti-MAG & $\begin{array}{l}\text { Myelin Associated } \\
\text { Glycoprotein (MAG) }\end{array}$ \\
\hline
\end{tabular}


medium confidence (0.4) in STRING with allowed 14 additional nodes automatically added by the software to increase a network connectivity. When the network map was enriched by tissue specificity (medium confidence- 0.400 , high-0.700), 8 of the nodes where linked to central nervous system and brain (Table 3 ). The proteins linked by biological processes are shown in Table 4 . Worth mentioning here, that one protein added by string to increase network connectivity, PIK3R1, had the molecular function of neurotrophin receptor binding.

The interactions with the know autism associated genes are shown in Figure 3. One can see that there are several most connected nodes in the network, namely: GRB2 (in the centre of the network, added as a white node), SHH, PIK3R1 and HDAC2 (which are proteins from the know autism associated genes). The analysis also shows that MBP is the main antigen that is associated with the know autism associated genes in the network map and the most of CNS GO terms.

Majority of network links found within the data were green, indicating text-mining associations. ADA, APP, CUL1, FHIT, GRPEL1 and ICT1 were ASD genes that were directly associated to the streptococcal infection gene set experimentally, which may be deemed more substantial than associations by textmining. Interestingly, although some of the genes had indirect associations through homologs. GRPEL1 has a homolog that is in the same gene neighbourhood as HSPD1. ADA, ABCC1, and that are co-expressed with genes triggered by streptococcal infection.

\section{Gene expression analysis}

Table 5 shows the genes from both gene sets that were highly expressed in the nervous system (NS) and immune system (IS). Interestingly for both groups, there were genes with high expression in each of these anatomic locations. Of note, APP, BCL11A and KLC1 from the ASD gene set were highly expressed in both the NS and IS. For the streptococcal infection gene set, some of the primary genes were highly expressed in NS or IS. HSPD1, MBP, GRB2 and HSP90AA1 were highly expressed in both anatomic regions.

Table 6 shows the top 10 general biological processes for the streptococcal-associated gene list. Interestingly, multiple NS pathways are associated with the streptococcal infection gene. See (Table 7), molecules of note that reoccur in different pathways (both NS and IS) include the primary streptococcal associated genes: HSPD1, MAG, $\mathrm{MBP}$, and the secondary streptococcal infection- associated genes: FGFR1, FGFR2, GRB2, HSP90AA1 and LYN.

\section{Pathway analysis}

Neural-associated diseases and functions for the streptococcallinked gene list indicated a function in neural development (Table 8).

The listed genes are essential for normal brain formation as seen with links to familial holoprosencephaly, formation of brain cells and

Table 3. Brain function-related ontologies of streptococcal infection-associated targets of autoantibodies

\begin{tabular}{|c|c|c|}
\hline Disease & Nodes & Proteins \\
\hline CNS Disease & 2 & MBP,HSPD1 \\
\hline Autoimmune Disease of the CNS & 1 & MBP \\
\hline Brain Disease & 1 & HSPD1 \\
\hline Autoimmune Disease of Gastrointestinal Tract & 1 & CD79A \\
\hline Disease of Mental Health & 2 & SYK, CASP3 \\
\hline ASD & 1 & Migh \\
\hline
\end{tabular}

Table 4. Enrichment of biological processes categories in the immediate proximal network reconstructed for proteins-targets of infection-induced autoantibodies

\begin{tabular}{|c|c|c|c|}
\hline Process & Nodes & P-value & Proteins \\
\hline Positive Regulation of Developmental Process & 6 & 0.01969 & IFITM1, BTK, SYK, LYN, ADA, CCL11 \\
\hline Negative Regulation of Developmental Process & 5 & 0.03849 & PIK3R1, LYN, MAPK1 MBP, MAG \\
\hline Organ Development & 9 & 0.0596 & CR2, PIK3R1, SYK, MBP, MAG, MAPK1, CD79A, ADA, CCL11 \\
\hline Substantia Nigra Development & 2 & 0.08279 & MAG,MBP \\
\hline Subthalamus Development & 2 & 0.08840 & MAG, MBP \\
\hline Neural Nucleus Development & 2 & 0.1419 & MAG, MBP \\
\hline Generation of Neurons & 5 & 0.2899 & MAG, MBP, MAPK1,CASP3, HSP90AA1 \\
\hline Neuron Differentiation & 3 & 0.2959 & MAG, MBP, LYN \\
\hline Diencephalon Development & 2 & 0.3150 & MAG, MBP \\
\hline Neurogenesis & 5 & 0.3469 & MAG, MBP, MAPK1, CASP3, HSP90AA1 \\
\hline Nervous System Development & 5 & 1 & MAG, MBP, MAPK1, CASP3, HSP90AA1 \\
\hline CNS Development & 3 & 1 & MAG,LYN MBP \\
\hline Forebrain development & 2 & 1 & MAG, MBP \\
\hline
\end{tabular}

Table 5. ASD and streptococcal associated genes that are highly expressed (mean score $\geq 6$ ) in the nervous or immune system according to mRNAseq data

\begin{tabular}{|c|c|c|}
\hline Gene list & Anatomic location & Genes \\
\hline ASD & Nervous system & $\begin{array}{l}\text { APP*, BCL11A*, CACNAI1I CADPS, CCDC64, CDH22, CNTNAP2, CTNNA2, DMD, DNER, DTNB, EPN2, } \\
\text { FAM171A1, FEZF2, FGF1, FHIT, GDAP1, GFAP, GRIN1, KLC1*, MAST3, MFSD6, MYO5A, NDFIP1, NTM, } \\
\text { PSD3, PTPRN2, RBFOX1, SH3GL3 }\end{array}$ \\
\hline ASD & Immune system & $\begin{array}{l}\text { APP*, ATXN2L, BCL11A*, CDC37, CSDE1, DYNLT1, ETS1, FLI1, IL17RA, KLC1*, LCP2, MSN, NDRG1, } \\
\text { PTPRE, RASGRP4, SEMA4D, SLTM, SP110, TBXAS1, TYK2 }\end{array}$ \\
\hline Streptococcal & Nervous system & 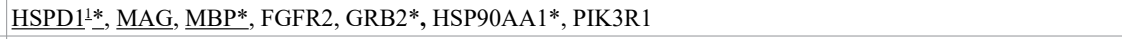 \\
\hline Streptococcal & Immune System & 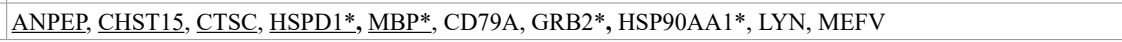 \\
\hline
\end{tabular}

*indicates genes that are highly expressed in both the nervous system and immune system within their own gene list ${ }^{1}$ underlined font indicates primary streptococcal-associated genes 


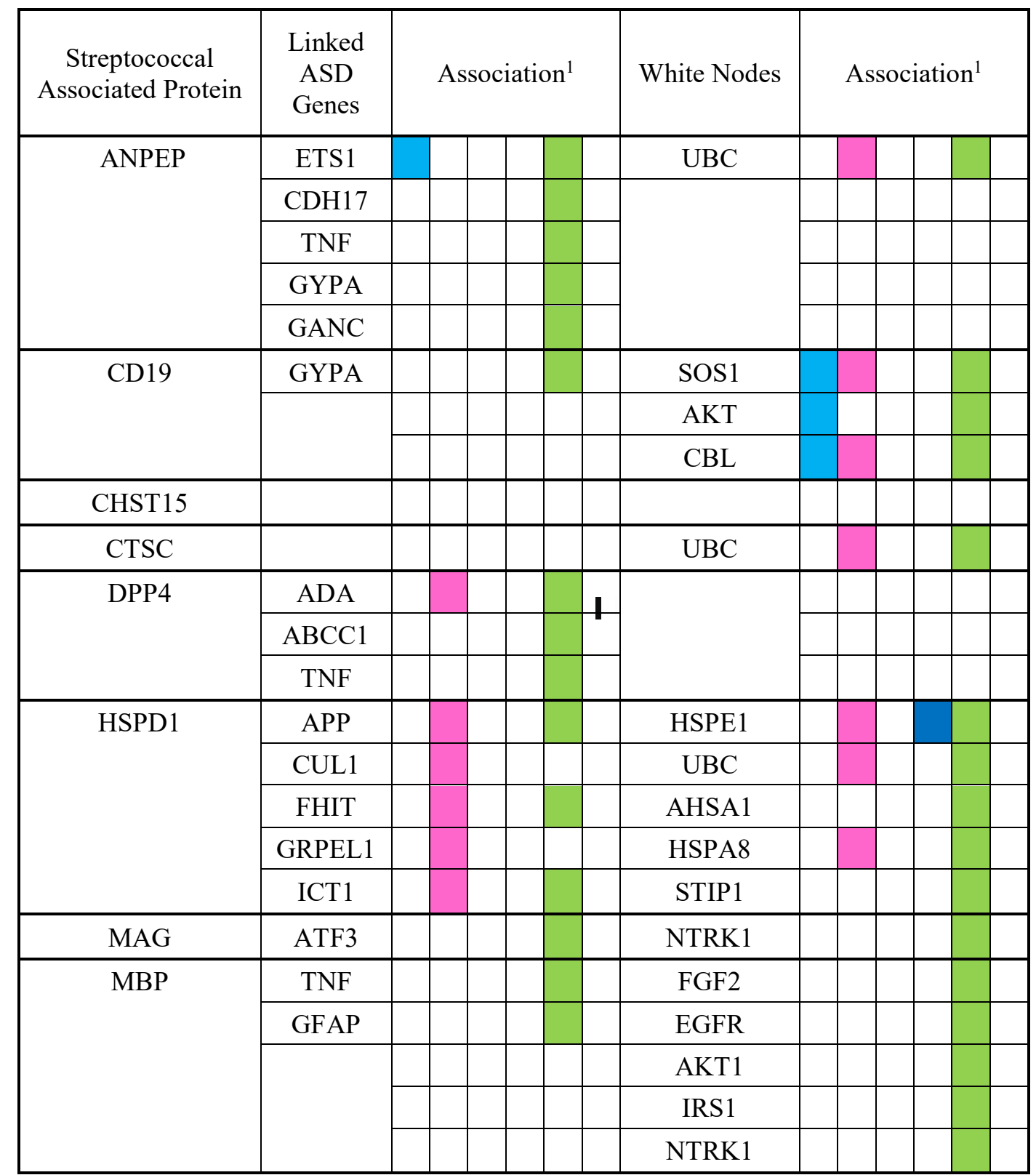

Figure 3. The different evidence found between the primary streptococcal-associated genes and ASD-associated genes at medium confidence (0.4). ${ }^{1}$ The different coloured boxes indicate different evidence; light blue $=$ associated in a curated database, dark green $=$ gene neighbourhood, dark blue $=$ gene co-occurrence, light green $=$ text mining and black $=$ coexpression. Striped boxes indicate that although the gene itself has no association, its homologous proteins do

Table 6. Top 10 general biological processes found from functional enrichment within the Streptococcal gene network using STRING

Pathway description

Neurotrophin TRK receptor signalling pathway

Fc receptor signalling pathway

Regulation of T cell activation

Cell morphogenesis involved in differentiation

Midbrain development

Neuron projection development

Locomotion

Positive regulation of $\mathrm{T}$ cell activation

Fc-epsilon receptor signalling pathway

Axonogenesis

${ }^{1}$ Primary streptococcal genes are underlined.

${ }^{2}$ The significance is expressed as a p-value, where significance is $p \leq 0.05$.
Molecules $^{1}$

FGFR1, FGFR2, HDAC2, CASP3, MAG, CD19, GRB2, PIK3R1

False discovery rate

$1.25 \mathrm{E}-05$

$5.14 \mathrm{E}-05$

$5.95 \mathrm{E}-05$

$6.45 \mathrm{E}-05$

$6.45 \mathrm{E}-05$

$6.45 \mathrm{E}-05$

$6.45 \mathrm{E}-05$

$6.45 \mathrm{E}-05$

$6.60 \mathrm{E}-05$

$8.48 \mathrm{E}-05$
CD19, LYN, FGFR1, FGFR2, PIK3R1, GRB2

SHH, FGFR1, FGFR2, HSP90AA1, LYN, GRB2, ST8SIA2, SLITRK5
HDAC2, SHH, FGFR1, FGFR2, HSP90AA1, LYN, GRB2, SLITRK5, ST8SIA2

DPP4, ANPEP, MAG, SIX3, SHH, SNAI1, HSP90AA1, LYN, PIK3R1, GRB2,

ST8SIA2

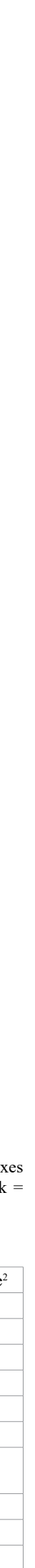


Table 7. Top 10 neural specific biological processes found from functional enrichment within the Streptococcal gene network using STRING

\begin{tabular}{|l|l|l|}
\hline Pathway description & Molecules $^{1}$ & False discovery rate $^{2}$ \\
\hline Neurotrophin TRK receptor signalling pathway & FGF1, FGFR2, HDAC2, CASP3, MAG, CD19, GRB2 \\
\hline Midbrain development & SHH, FGFR1, FGFR2, MBP, MAG \\
\hline Neuron projection development & HDAC2, SHH, FGFR1, FGFR2, HSP90AA1, LYN, GRB2, SLITRK5, ST8SIA2 \\
\hline Axonogenesis & SHH, FGFR1, FGFR2, HSP90AA1, LYN, GRB2, ST8SIA2, SLITRK5 \\
\hline Axon development & SHH, HSP90AA1, FGFR1, FGFR2, LYN, GRB2, ST8SIA2, SLITRK5 \\
\hline $\begin{array}{l}\text { Cell morphogenesis involved in neuron differentiation } \\
\text { Positive regulation of gliogenesis }\end{array}$ & SHH, HSP90AA1, FGFR1, FGFR2, LYN, GRB2, ST8SIA2, SLITRK5 \\
\hline $\begin{array}{l}\text { CNS development } \\
\text { Neural precursor cell proliferation }\end{array}$ & HDAC2, SHH, LYN, MAG \\
\hline $\begin{array}{l}\text { FGF signalling receptor pathway involved in orbitofrontal cortex } \\
\text { development }\end{array}$ & SHH, FGFR1, FGFR2, LYN, CASP3, MBP, MAG, MOG, SLITRK5 \\
\hline
\end{tabular}

${ }^{1}$ Primary streptococcal genes are underlined.

${ }^{2}$ The significance is expressed as a p-value, where significance is $p \leq 0.05$

Table 8. The top ten brain and neural-linked diseases and functions categories detected in the immediate functional connectivity proximity of the Streptococcal infection-associated gene set by IPA software

\begin{tabular}{|c|c|c|}
\hline Diseases or Functions Annotation & Molecules $^{1}$ & $p$-value ${ }^{2}$ \\
\hline Development of central nervous system & $\begin{array}{l}\text { CASP3, EXOC4, FGFR1, FGFR2, HDAC2, MAG, MBP, MOG, SHH, SIX3, SLITRK5, } \\
\text { ST8SIA2 }\end{array}$ & $1.53 \mathrm{E}-10$ \\
\hline Neuritogenesis & CASP3, FGFR1, FGFR2, HDAC2, LYN, $\underline{\text { MAG, }}$ MBP, MOG, MYO5B, SHH, SLITRK5 & $1.33 \mathrm{E}-09$ \\
\hline Development of neurons & $\begin{array}{l}\text { CASP3, FGFR1, FGFR2, HDAC2, LYN, MAG, MBP, MOG, MYO5B, SHH, SLITRK5, } \\
\text { ST8SIA2 }\end{array}$ & $2.45 \mathrm{E}-09$ \\
\hline Differentiation of nervous system & EXOC4, FGFR1, FGFR2, HDAC2, MAG, SHH, SIX3, SNAI1, ST8SIA2 & $3.35 \mathrm{E}-08$ \\
\hline Familial holoprosencephaly & FGFR1, SHH, SIX3 & $1.05 \mathrm{E}-07$ \\
\hline Hypomyelination & FGFR1, $\underline{\text { HSPD1}}, \underline{\text { MAG, }} \underline{\text { MBP }}$ & $3.39 \mathrm{E}-07$ \\
\hline Formation of brain cells & FGFR1, FGFR2, SHH, ST8SIA2 & $8.13 \mathrm{E}-07$ \\
\hline Abnormal morphology of central nervous system & CASP3, FGFR1, FGFR2, HDAC2, $\underline{\text { MAG, }}$ MBP, SHH, ST8SIA2 & $9.06 \mathrm{E}-07$ \\
\hline Dysmyelination & CD19, FGFR1, $\underline{\text { HSPD1, MAG, MOG }}$ & $1.45 \mathrm{E}-06$ \\
\hline Transformation of mesencephalon & FGFR1, FGFR2 & $1.59 \mathrm{E}-06$ \\
\hline
\end{tabular}

transformation of mesencephalon. The development of the central nervous system is strongly linked to the set of infections-associated genes (with a strong p-value of 1.53E-10) (Figure 4) and their effect on dysmyelination is illustrated in Figure 5. IPA was used to construct networks of the genes associated with Streptococcal infection. The links formed are predominantly of protein-protein interactions.

Interactions were visualised to see if any of the genes have joined functional roles, and to aid in constructing a mechanism of etiology for ASD. Figure 6 shows a top populated network (IPA) for the streptococcal infection gene set with links to infection and inflammation categories, but also to multiple NS -associated diseases and functions. Of the primary streptococcal infection associated genes, CD19, HSPD1, MAG and MBP are heavily connected to other genes in the network, as well as to the associated diseases and functions. Of the secondary streptococcal infection associated molecules, BCR (complex), CASP3, PI3K, and CD79A are well connected to both molecules and functions. The network also includes nodes corresponding to molecules automatically added by the software, such as multiple immunoglobulins, which highlights the theme of antibodies. Interestingly, of these molecules added by IPA, are some of the ASD-associated genes such as, APP and IL1RN. One can see that there are several nodes in the network, highly connected to the seed genes: GRB2 (in the centre of the network, added as a white node), SHH, PIK3R1 and HDAC2 (which are proteins of genes know to be associated with ASD). The analysis also shows that MBP is the main antigen that is associated in networks with ASDattributed functions and also matches to the most of network's CNSrelevant GO-terms.

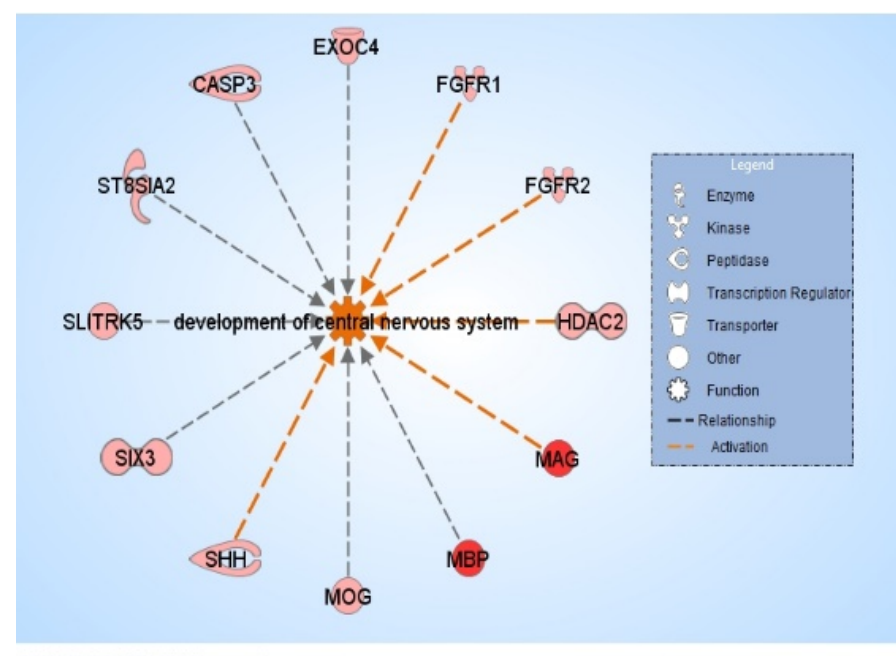

2 2000-2016 QLAGEN.All rights reserved

Figure 4. Visualisation of the molecule interactions for 'development of central nervous system' from Table 11, showing the streptococcal-associated genes involved. Primary streptococcal genes are indicated by red shaped whilst their directly linked genes are indicated by pink shapes. As shown in the legend orange lines indicate activation, whilst grey lines indicate a relationship that has not been fully determined.

\section{Discussion}

\section{Roles and functions of the genes}

Results from GWAS studies suggest that ASD-associated genes have a role in development and synapse maintenance, and are expressed in areas of the brain such as the frontal and temporal cortex $[12,45,46]$. 


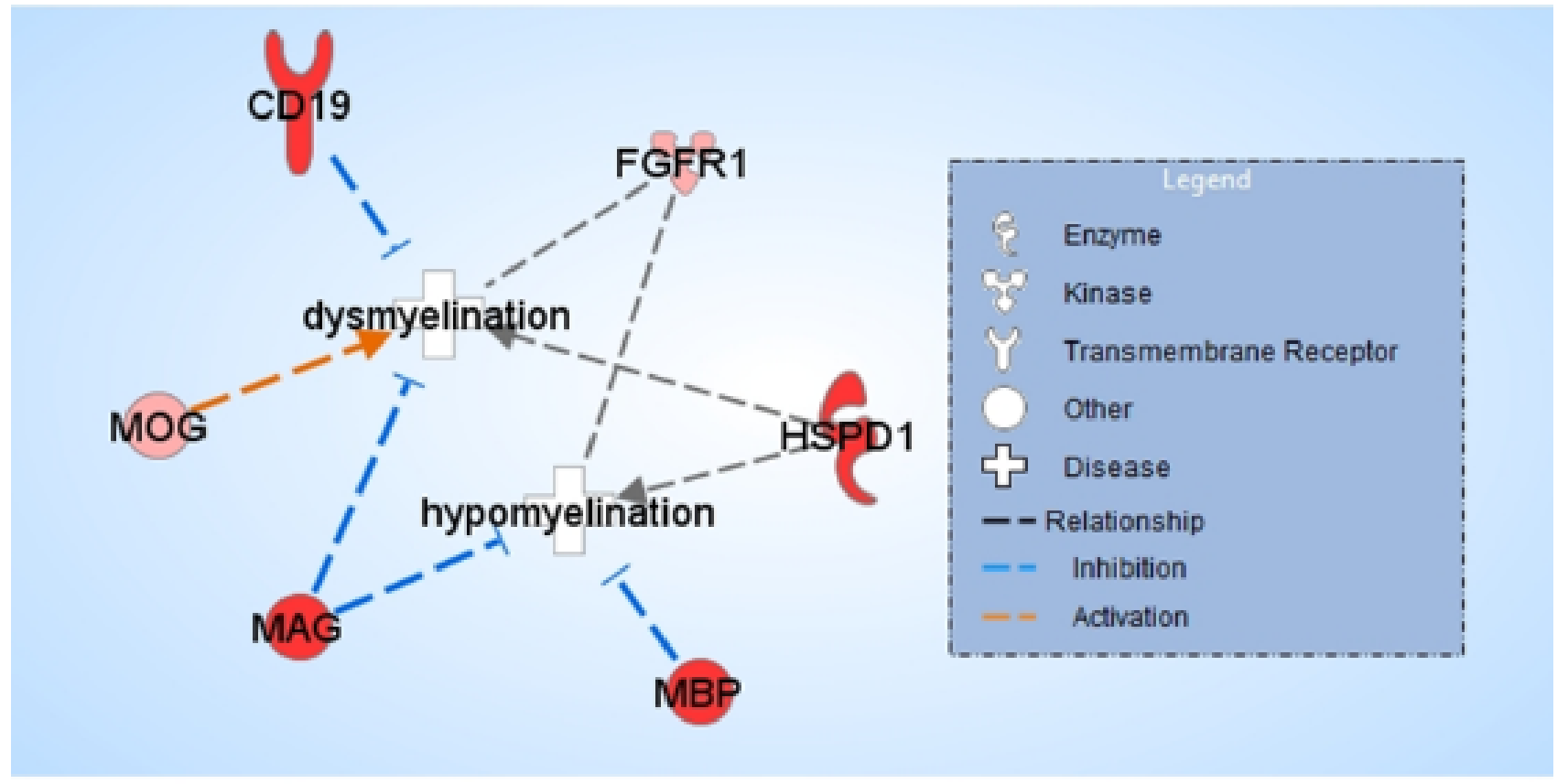

\section{(9) 2000-2016 QIAGEN. All rights reserved.}

Figure 5. Visualisation of the molecule interactions for 'hypomyelination' and 'dysmyelination' from Table 8, showing the streptococcal-associated genes involved. Primary streptococcal genes are indicated by red shaped whilst secondary streptococcal genes are indicated by pink shapes. As shown in the legend orange lines indicate activation, blue lines indicate inhibition whilst grey lines indicate a relationship that has not been fully determined

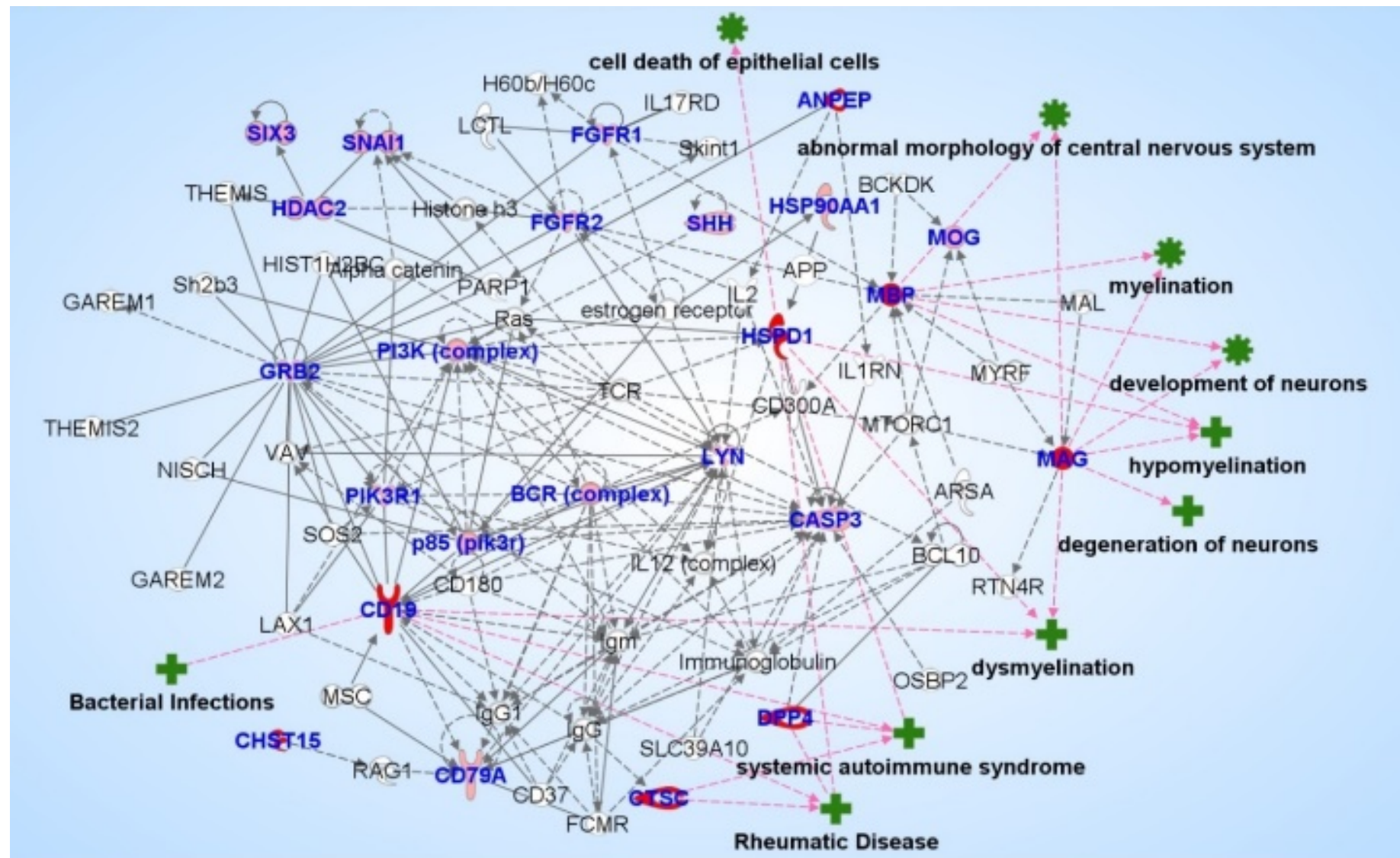

Figure 6. Network reconstructed in IPA from the streptococcal infection associated genes. All genes in lists are indicated by blue font. Shapes shaded red are for primary streptococcal genes and pink for their direct immediately connected genes. Solid lined indicate known direct interactions and dashed lines indicate indirect interactions. Diseases and functions associated with the network are linked by pink lines and are labelled in bold green font. Shapes represent molecular functions (cytokines-as for CD18, receptors-as FGFR1, proteases-as CASP3, TFs-as SIX3, other or combined functions-circles). 
Interestingly, HSPD1, MBP, GRB2 and HSP90AA1 are highly expressed in both the IS and NS and may link to microglia in the brain, particularly as HSPs activate and can be expressed by microglia $[47,48]$. Gene enrichment analysis clearly show that the streptococcalassociated genes are linked to both the IS and NS (Table 5). The streptococcal-associated genes are well linked to biological processes such as Neurotrophin TRK receptor signalling, $\mathrm{T}$ cell activation, locomotion, combining both IS, and NS functions (Table 6). Of note, the genes are linked to midbrain development and CNS development (Table 7). This is interesting when we consider the paediatric onset of ASD, as these genes are likely to be active and therefore available to be targeted by streptococcal autoantibodies. The main primary streptococcal genes involved in NS development include MAG and MBP whereas most of the other genes are more associated with the IS (Table 8). MAG and MBP are also associated with abnormalities in the NS, such as Hypomyelination and Dysmyelination (Table 8 and Figure 5). These results allow us to suggest that streptococcal infections may indeed affect the brain development and function.

\section{Genes of note}

Many ASD-associated genes are particularly expressed and associated within the IS include, APP, BCL11A, KLC1, ETS1, MET, IL1RN, NDRG1, NGF, TNF and VEGF (Table 5). These genes are receptors (APP, MET, IL1RN), involved in angiogenesis (NDRG1, VEGF), cell maintenance and development (BCL11A, KLC1, NGF,) and inflammation (ETS1, TNF). APP, ETS1, TNF and VEGF may be of a particular interest. APP encodes for the amyloid beta precursor protein, which is highly expressed in neurons and glial cells [49-51]. However, APP products also have a functional role, including synaptic adhesion, neuroprotective properties and antimicrobial functions [52-54]. APP transport in the brain is mediated by subunits formed by KLC1 molecules [55]. ETS1 encodes for ETS proto-oncogene 1, a transcription factor that has roles in inflammation and chemokine and cytokine activation particularly in endothelial cells and links to reactive microglia [56,57]. ETS-1 has been shown to co-localise with VEGF, TNF and APP products in the brain [57]. Vascular endothelial growth factors (VEGF) are a family associated with endothelial cell regulation and angiogenesis, even influencing the blood-brain barrier (BBB) $[58,59]$. Notably, VEGF appears to be able to alter the permeability of the BBB, and can increase permeability and cause breakdown [59-61]. Tumour necrosis factor (TNF) is a proinflammatory cytokine and is implicated in numerous functions and pathologies. TNF is implicated in inflammation and can affect the permeability of the BBB [62]. Of the streptococcal-associated genes, autoantibody targets MAG and MBP are the most prominent. MAG encodes for myelin-associated glycoprotein, a membrane protein that inhibits nerve regeneration [63]. MBP encodes for myelin basic protein, which is a major protein of the myelin sheath and has a regulatory role in myelination [64].

\section{Potential mechanism}

Our vision of how streptococcal infections can cause ASD in children is presented in Figure 7. Alterations in ETS1, TNF or VEGF functions, or their combination can decrease the permeability of the BBB and leave an individual vulnerable to toxic or autoimmune components developed due to an infection. Mutations may not act directly upon these genes but may affect their expression and protein proliferation $[65,66]$. This may be a result of mutations in promoter regions or polymorphisms in cytokines (TNF) or may be an upstream molecule [67-69]. VEGF and ETS1 have been associated with TNF in Alzheimer's disease [57]; therefore, we can conceive that they work functionally

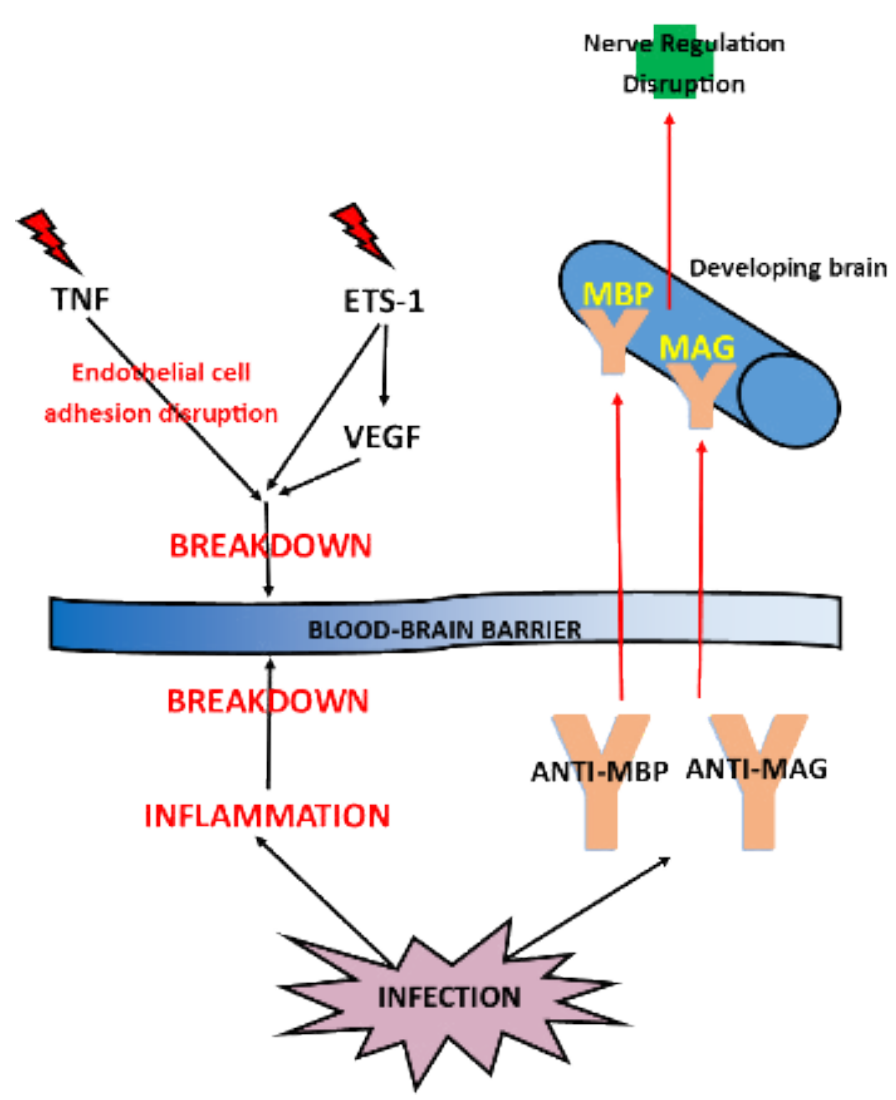

Figure 7. A proposed hypothesis for paediatric streptococcal-induced ASD, produced from the results of this study. Red bolts indicate a possible mutation affecting the gene either directly or upstream, red text indicates a negative effect, orange Y-shapes indicate antibodies and the green cross indicates pathology.

together in the brain. ETS1 and VEGF can induce microglial activity towards increased TNF production [57,70-72]. Additionally VEGF expression in astrocytes, a component of the BBB, can induce the BBB breakdown [73], supported by a streptococcal- induced inflammation. Streptococcal infections produce autoantibodies against MAG and MBP. With a weakened BBB, anti-MAG and anti-MBP can travel across and target developing neurones for destruction by immune cells able to cross the weakened BBB. In fact, thinner myelination has been reported in some areas of the brain in ASD, such as the orbitofrontal cortex (OFC), as well as a high density of thinly myelinated neurons when compared to controls [74]. OFC abnormalities have already been associated with ASD and it is speculated that a decrease in myelin may mean that longer axons that provide the cross talk for emotionbased behaviors are less efficient $[75,76]$. From the other hand, neurite overgrowth found in ASD patients [77,78] may be explained by MAG (inhibitor of neurite regrowth) immuno- inhibition.

\section{Conclusions}

From published and our study it is clear that there is overlap within the IS and NS functions that may be responsible for synergism in inheritable and environmental components in aetiology of a number of neuro-psychiatric disorder, and ASD, in particular. APP, BCL11A, KLC1, ETS1, MET, IL1RN, NDRG1, NGF, TNF, VEGF, HSPD1, MAG and MBP proteins are likely candidates to affect susceptibility to the environmental component. What is notable is that many of these genes were identified to have roles in the developing brain, reflecting the paediatric nature. Despite a proposed theory (Figure 7), uncertainties 
remain as to how some of these genes may interact to affect ASD. We suggest that APP, HSPD1, MET and NDRG1 may be implicated in the reaction caused by the autoantibodies. Those would be ideal candidates to investigate further using experimental methods in animal models or to be tested for in cases of PANDAS or more profound ASD cases in children.

\section{Acknowledgements}

The authors are very grateful to the University of Liverpool's School of Life Sciences for a support of this research.

\section{Conflicts of interests}

The authors do not have any conflicting interests relevant to this study.

\section{Author's contributions}

OV has designed and supervised the study, $\mathrm{MH}$ and JS made equal contributions to data generation, all authors played equal roles in the data analysis and drafting of the manuscript.

\section{References}

1. Wills S, Cabanlit M, Bennett J, Ashwood P, Amaral D, et al. (2007) Autoantibodies in autism spectrum disorders (ASD). Ann N Y Acad Sci 1107: 79-91. [Crossref]

2. The NHS Information Centre, Community and Mental Health Team, Brugha, $\mathrm{T}$ et al. (2012) Estimating the prevalence of autism spectrum conditions in adults: extending the 2007 Adult Psychiatric Morbidity Survey. Leeds: NHS Information Centre for Health and Social Care. [Crossref]

3. Hallmayer J, Cleveland S, Torres A, Phillips J, Cohen B, et al. (2011) Genetic heritability and shared environmental factors among twin pairs with autism. Arch Gen Psychiatry 68: 1095-1102. [Crossref]

4. Stefferl A, Schubart A, Storch M, et al. (2000) Butyrophilin, a milk protein, modulates the encephalitogenic $\mathrm{T}$ cell response to myelin oligodendrocyte glycoprotein in experimental autoimmune encephalomyelitis. J Immunol 165: 2859-2865. [Crossref]

5. Rodier PM, Ingram JL, Tisdale B, Nelson S, Romano J (1996) Embryological origin for autism: developmental anomalies of the cranial nerve motor nuclei. J Comp Neurol 370: 247-261. [Crossref]

6. Gardener H, Spiegelman D, Buka SL (2009) Prenatal risk factors for autism: comprehensive meta-analysis. Br J Psychiatry 195: 7-14. [Crossref]

7. Ellegood J, Anagnostou E, Babineau BA, Crawley JN, Lin L, et al. (2015) Clustering autism: using neuroanatomical differences in 26 mouse models to gain insight into the heterogeneity. Mol Psychiatry 20: 118-125. [Crossref]

8. Chiocchetti AG, Kopp M, Waltes R, Haslinger D, Duketis E, et al. (2015) Variants of the CNTNAP2 5' promoter as risk factors for autism spectrum disorders: a genetic and functional approach. Mol Psychiatry 20: 839-849. [Crossref]

9. Durand CM, Betancur C, Boeckers TM, et al. (2007) Mutations in the gene encoding the synaptic scaffolding protein SHANK3 are associated with autism spectrum disorders. Nat Genets 39: 25-27. [Crossref]

10. Peça J, Feliciano C, Ting JT, Wang W, Wells MF, et al. (2011) Shank3 mutant mice display autistic-like behaviours and striatal dysfunction. Nature 472: 437-442. [Crossref]

11. Campbell DB, Sutcliffe JS, Ebert PJ, Militerni R, Bravaccio C, et al. (2006) A genetic variant that disrupts MET transcription is associated with autism. Proc Natl Acad Sci U $S$ A 103: 16834-16839. [Crossref]

12. Voineagu I, Wang X, Johnston P, et al. (2011) Transcriptomic analysis of autistic brain reveals convergent molecular pathology. Nature 474: 380-384. [Crossref]

13. Yonk LJ, Warren RP, Burger RA, Cole P, Odell JD, et al. (1990) CD4+ helper T cell depression in autism. Immunol Lett 25: 341-345. [Crossref]

14. Molloy CA, Morrow AL, Meinzen-Derr J, Schleifer K, Dienger K, et al. (2006) Elevated cytokine levels in children with autism spectrum disorder. J Neuroimmunol 172: 198205. [Crossref]

15. Li X, Chauhan A, Sheikh AM, Patil S, Chauhan V, et al. (2009) Elevated immune response in the brain of autistic patients. J Neuroimmunol 207: 111-116. [Crossref]
16. Singh WK, Warren RP, Odell JD, Warren WL and Cole P (1993) Antibodies to myelin basic protein in children with autistic behavior. Brain Behav Immun 7: 97-103. [Crossref]

17. Singh VK, Warren R, Averett R, Ghaziuddin M (1997) Circulating autoantibodies to neuronal and glial filament proteins in autism. Pediatr Neurol 17: 88-90. [Crossref]

18. Cabanlit M, Wills S, Goines P, Ashwood P, Van de Water J (2007) Brain-specific autoantibodies in the plasma of subjects with autistic spectrum disorder. Ann N Y Acad Sci 1107: 92-103. [Crossref]

19. Mostafa GA, El-Sayed ZA, El-Aziz MMA, El-Sayed MF (2008) Serum anti- myelinassociated glycoprotein antibodies in Egyptian autistic children. $J$ Child Neurol 23: 1413-1418. [Crossref]

20. Kalra S, Burbelo PD, Bayat A, Ching KH, Thurm A, et al. (2015) No Evidence of Antibodies against GAD65 and Other Specific Antigens in Children with Autism. BBA Clin 4: 81-84. [Crossref]

21. Swedo SE, Leonard HL, Mittleman BB, et al. (1997) Identification of children with pediatric autoimmune neuropsychiatric disorders associated with streptococcal infections by a marker associated with rheumatic fever. Am J Psychiatry 154: 110-112. [Crossref]

22. Storch EA, Geffken GR, Murphy TK eds. (2012) Handbook of child and adolescent obsessive-compulsive disorder. Routledge. [Crossref]

23. Snider LA, Swedo SE (2003) Post-streptococcal autoimmune disorders of the central nervous system. Curr Opin Neurol 16: 359-365. [Crossref]

24. Peterson BS, Leckman JF, Tucker D, et al. (2000) Preliminary findings of antistreptococcal antibody titers and basal ganglia volumes in tic, obsessivecompulsive, and attention- deficit/hyperactivity disorders. Arch Gen Psychiatry 57: 364-372. [Crossref]

25. Hoekstra PJ, Kallenberg CG, Korf J, Minderaa RB (2002) Is Tourette's syndrome an autoimmune disease? Mol Psychiatry 7: 437-445. [Crossref]

26. Murphy ML and Pichichero ME (2002) Prospective identification and treatment of children with pediatric autoimmune neuropsychiatric disorder associated with group A streptococcal infection (PANDAS). Arch Pediatr Adolesc Med 56: 356-361. [Crossref]

27. Martino D, Zis P, Buttiglione M (2015) The role of immune mechanisms in Tourette syndrome. Brain Res 1617: 126-143. [Crossref]

28. Anney R., Klei L, Pinto D, Almeida J, Bacchelli E, et al. (2012) Individual common variants exert weak effects on the risk for autism spectrum disorders. Hum Mol Gen 21: 4781-4792. [Crossref]

29. Chaste P, Klei L, Sanders SJ, et al. (2015) A genome-wide association study of autism using the Simons Simplex Collection: Does reducing phenotypic heterogeneity in autism increase genetic homogeneity? Biol Psychiatry 77: 775-784. [Crossref]

30. St Pourcain B, Skuse DH, Mandy WP, et al. (2014) Variability in the common genetic architecture of social-communication spectrum phenotypes during childhood and adolescence. Mol Autism 5: 18. [Crossref]

31. Xia K, Guo H, Hu Z, Xun G, Zuo L, et al. (2014) Common genetic variants on 1p13.2 associate with risk of autism. Mol Psychiatry 19: 1212-1219. [Crossref]

32. American Psychiatric Association (2013) Diagnostic and statistical manual of menta disorders (DSM-5®). American Psychiatric Pub. [Crossref]

33. Weisz JL, McMahon WM, Moore JC, et al. (2004) D8/17 and CD19 Expression on Lymphocytes of Patients with Acute Rheumatic Fever and Tourette's Disorder. Clin Diagn Lab Immunol 11: 330-336. [Crossref]

34. Hollander E, DelGiudice-Asch G, Simon L, Schmeidler J, Cartwright C, et al. (1999) B lymphocyte antigen D8/17 and repetitive behaviors in autism. Am J Psychiatry 156 317-320. [Crossref]

35. Vojdani A, Bazargan M, Vojdani E, et al. (2004) Heat shock protein and gliadin peptide promote development of peptidase antibodies in children with autism and patients with autoimmune disease. Clin Diagn Lab Immunol 11: 515-524. [Crossref]

36. Mostafa GA, Al-Ayadhi LY (2011) Increased serum levels of anti-ganglioside M1 autoantibodies in autistic children: relation to the disease severity. J Neuroinflammation 8: 39. [Crossref]

37. Mostafa GA and Kitchener N (2009) Serum anti-nuclear antibodies as a marker of autoimmunity in Egyptian autistic children. Pediatric neurology 40: 107-112. [Crossref]

38. Keszler G, Kruk E, Kenezloi E, Tarnok Z, Sasvari-Szekely M, et al. (2014) Association of the tumor necrosis factor $-308 \mathrm{~A} / \mathrm{G}$ promoter polymorphism with Tourette syndrome. Int J Immunogenet 41: 493-498. [Crossref] 
39. Gonzalez-Gronow M, Cuchacovich M, Francos R, Stephanie Cuchacovich, Maria del Pilar, et al. (2010) Antibodies against the voltage-dependent anion channel (VDAC) and its protective ligand hexokinase-I in children with autism. $J$ Neuroimmunol 227: 153-161. [Crossref]

40. Matho MH, de Val N, Miller GM, Brown J, Schlossman A, et al. (2014) Murine antivaccinia virus $\mathrm{D} 8$ antibodies target different epitopes and differ in their ability to block D8 binding to CS- E. PLoS Pathol 10: e1004495. [Crossref]

41. Matteucci E, Giampietro O (2009) Dipeptidyl peptidase-4 (CD26): knowing the function before inhibiting the enzyme. Curr Med Chem 16: 2943-2951. [Crossref]

42. Kominami E, Ishido K, Muno D, Sato N (1992) The primary structure and tissue distribution of cathepsin C. Biol Chem Hoppe Seyler 373: 367-373. [Crossref]

43. Shoenfeld $Y$ and Gershwin M E eds (2009) Contemporary challenges in autoimmunity. John Wiley \& Sons.

44. Barton DE, Arquint M, Roder J, Dunn R and Francke U (1987) The myelin-associated glycoprotein gene: mapping to human chromosome 19 and mouse chromosome 7 and expression in quivering mice. Genomics 1: 107-112. [Crossref]

45. Sanders SJ, Murtha MT, Gupta AR, et al. (2012) De novo mutations revealed by wholeexome sequencing are strongly associated with autism. Nature 485: 237-241. [Crossref]

46. De Rubeis S, He X, Goldberg AP, Poultney CS, Samocha K, et al. (2014) Synaptic, transcriptional and chromatin genes disrupted in autism. Nature 515: 209-215. [Crossref]

47. Acarin L, Paris J, González B, Castellano B (2002) Glial expression of small heat shock proteins following an excitotoxic lesion in the immature rat brain. Glia 38: 1-14. [Crossref]

48. Kakimura J, Kitamura Y, Takata K, Umeki M, Suzuki S, et al. (2002) Microglial activation and amyloid-beta clearance induced by exogenous heat-shock proteins. FASEB J 16: 601-603. [Crossref]

49. Banati RB, Gehrmann J, Wiessner C, Hossmann KA and Kreutzberg GW (1995) Glial expression of the $\alpha$-amyloid precursor protein (APP) in global ischemia. $J$ Cereb Blood FlowMetab 15: 647-654. [Crossref]

50. Kang J, Lemaire HG, Unterbeck A, Salbaum JM, Masters CL, et al. (1987) The precursor of Alzheimer's disease amyloid A4 protein resembles a cell-surface receptor. Nature 325: 733-736. [Crossref]

51. Citron M, Oltersdorf T, Haass C, et al. (1992) Mutation of the $\beta$-amyloid precursor protein in familial Alzheimer's disease increases beta-protein production. Nature 360 : 672-674. [Crossref]

52. Soba P, Eggert S, Wagner K, Zentgraf H, Siehl K, et al. (2005) Homo- and heterodimerization of APP family members promotes intercellular adhesion. EMBO $J$ 24: 3624-3634. [Crossref]

53. Copanaki E, Chang S, Vlachos A, Tschäpe JA, Müller UC, et al. (2010) sAPPalpha antagonizes dendritic degeneration and neuron death triggered by proteasomal stress. Mol Cell Neurosci 44: 386-393. [Crossref]

54. Soscia SJ, Kirby JE, Washicosky K.J, et al. (2010) The Alzheimer's disease-associated amyloid alpha-protein is an antimicrobial peptide. PloS one 5: e9505. [Crossref]

55. Kamal A, Stokin GB, Yang Z, Xia CH and Goldstein LS (2000) Axonal transport of amyloid precursor protein is mediated by direct binding to the kinesin light chain subunit of kinesin-I. Neuron 28: 449-459. [Crossref]

56. Zhan Y, Brown C, Maynard E, Anshelevich A, Ni W, et al. (2005) Ets-1 is a critical regulator of Ang II-mediated vascular inflammation and remodeling. J Clin Invest 115 : 2508-2516. [Crossref]

57. Jantaratnotai N, Ling A, Cheng J, Schwab C, McGeer PL, et al. (2013) Upregulation and expression patterns of the angiogenic transcription factor ets-1 in Alzheimer's disease brain. J Alzheimers Dis 37: 367-377. [Crossref]

58. Ferrara N and Henzel WJ (1989) Pituitary follicular cells secrete a novel heparinbinding growth factor specific for vascular endothelial cells. Biochem Biophys Res Com 161: 851-858. [Crossref]
59. Zhang Z., Zhang L, Jiang Q, et al. (2000) VEGF enhances angiogenesis and promotes blood-brain barrier leakage in the ischemic brain. J Clin Invest 106: 829-838. [Crossref]

60. Mayhan WG (1999) VEGF increases permeability of the blood-brain barrier via a nitric oxide synthase/cGMP-dependent pathway. Am J Physiol-Cell Physiol 276: C1148-C1153. [Crossref]

61. Argaw AT, Gurfein BT, Zhang Y, Zameer A, John GR (2009) VEGF-mediated disruption of endothelial CLN-5 promotes blood-brain barrier breakdown. Proc Natl Acad Sci U S A 106: 1977-1982. [Crossref]

62. Mark KS and Miller DW (1999) Increased permeability of primary cultured brain microvessel endothelial cell monolayers following TNF-alpha exposure. Life Sci 64: 1941-1953. [Crossref]

63. Mukhopadhyay G, Doherty P, Walsh FS, Crocker PR, Filbin MT (1994) A novel role for myelin-associated glycoprotein as an inhibitor of axonal regeneration. Neuron 13: 757-767. [Crossref]

64. Pedraza L, Fidler L, Staugaitis SM, DR (1997) The active transport of myelin basic protein into the nucleus suggests a regulatory role in myelination. Neuron 18: 579-589. [Crossref]

65. Vargas DL, Nascimbene C, Krishnan C, Zimmerman AW, Pardo CA (2005) Neuroglial activation and neuroinflammation in the brain of patients with autism. Ann Neurol 57: 67-81. [Crossref]

66. Krakowiak P, Goines PE, Tancredi DJ, Ashwood P, et al. (2017) Neonatal Cytokine Profiles Associated With Autism Spectrum Disorder. Biol Psychiatry 81: 442-451. [Crossref]

67. Knight J (2001) Polymorphisms in tumor necrosis factor and other cytokines as risks for infectious diseases and the septic syndrome. Curr Inf Dis Rep 3: 427-439. [Crossref]

68. Kähler AK, Persson AS, Sanchez F, Källström H, Apt AS, et al. (2005) A new coding mutation in the Tnf-alpha leader sequence in tuberculosis-sensitive I/St mice causes higher secretion levels of soluble TNF-alpha. Genes Immun 6: 620-627. [Crossref]

69. Wu WS and McClain KL (1997) DNA polymorphisms and mutations of the tumor necrosis factor-alpha (TNF-alpha) promoter in Langerhans cell histiocytosis (LCH). $J$ Interferon Cytokine Res 17: 631-635. [Crossref]

70. Meda L, Cassatella M., Szendrei GI, et al. (1995) Activation of microglial cells by betaamyloid protein and interferon-gamma. Nature 374: 647-650. [Crossref]

71. Renno T, Krakowski M, Piccirillo C, Lin JY, Owens T (1995) TNF-alpha expression by resident microglia and infiltrating leukocytes in the central nervous system of mice with experimental allergic encephalomyelitis. Regulation by Th1 cytokines. J Immunol 154: 944-953. [Crossref]

72. Forstreuter F, Lucius R and Mentlein R (2002) Vascular endothelial growth factor induces chemotaxis and proliferation of microglial cells. J Neuroimmunol 132: 93-98. [Crossref]

73. Chapouly C, Argaw,AT, Horng S, Castro K, Zhang J, et al. (2015) Astrocytic TYMP and VEGFA drive blood-brain barrier opening in inflammatory central nervous system lesions. Brain 138: 1548-1567. [Crossref]

74. Zikopoulos B and Barbas H (2013) Altered neural connectivity in excitatory and inhibitory cortical circuits in autism. Front Hum Neurosci 7: 609. [Crossref]

75. Girgis RR, Minshew N, Melhem NM, Nutche JJ, Keshavan MS, et al. (2007) Volumetric alterations of the orbitofrontal cortex in autism. Progress in NeuroPsychopharmacology and Biol Psychiatry 31: 41-45. [Crossref]

76. Loveland KA, Bachevalier J, Pearson DA, Lane DM (2008) Fronto-limbic functioning in children and adolescents with and without autism. Neuropsychologia 46: 49-62. [Crossref]

77. McKerracher LD, David S, Jackson DL, Kottis V, Dunn RJ, et al. (1994) Identification of myelin-associated glycoprotein as a major myelin-derived inhibitor of neurite growth. Neuron 13: 805-811. [Crossref]

78. Courchesne E, Mouton PR, Calhoun ME, Semendeferi K, Ahrens-Barbeau C, et al. (2011) Neuron number and size in prefrontal cortex of children with autism. JAMA 306: 2001-2010. [Crossref]

Copyright: $\odot 2017$ Huxley M. This is an open-access article distributed under the terms of the Creative Commons Attribution License, which permits unrestricted use, distribution, and reproduction in any medium, provided the original author and source are credited. 